\title{
EKSISTENSI YESUS PASCA KENAIKANNYA: Refleksi Teologis di Gereja Banua Niha Keriso
}

\author{
Arif Yupiter Gulo, ${ }^{1}$ Bobby Kurnia Putrawan ${ }^{2 *}$ \\ Sekolah Tinggi Teologi Pokok Anggur, Indonesia ${ }^{1}$ \\ Sekolah Tinggi Teologi Moriah, Indonesia ${ }^{2}$ \\ Email: glyupiarif@gmail.com, ${ }^{1}$ bkputrawan@gmail.com ${ }^{1 *}$
}

\begin{abstract}
This article discusses contextual theology about the existence of Jesus after His ascension in the Protestant Banua Niha Keriso Church. Contextualization is an attempt to make the existence of Jesus relevant in every context in ministry. Jesus Christ was not only a perfect man but also a true God. Even though He has ascended to heaven in the glory of His Father, in a divine manner, He has not left His people. This paper uses a qualitative research method by collecting data and other scientific articles. In this discussion, we find that Jesus as God is present in the midst of His people by going above and beyond the context of human life by emphasizing the church as God's representative in declaring truth and change.
\end{abstract}

Keywords: Contextual, Jesus Existence, Church of Banua Niha Keriso

\begin{abstract}
Abstrak
Artikel ini membahas tentang refleksi teologi kontekstual tentang eksistensi Yesus pasca kenaikan-Nya di Gereja Banua Niha Keriso Protestan. Kontekstualisasi merupakan upaya bagaimana eksistensi Yesus menjadi relevan dalam setiap konteks dalam pelayanan. Yesus Kristus bukan hanya manusia yang sempurna akan tetapi Ia juga Allah yang sejati. Kendati Ia sudah naik ke sorga dalam kemuliaan Bapa-Nya, secara ke-Allahan, Ia tidak meninggalkan umat-Nya. Tulisan ini dengan metode penelitian kualitatif dengan mengumpulkan data-data dan artikel-artikel ilmiah lainnya. Dalam pembahasan ini menemukan bahwa Yesus sebagai Allah hadir ditengah-tengah umat-Nya dengan melebihi dan melampaui konteks kehidupan manusia dengan menekankan gereja sebagai wakil Allah Dalam menyatakan kebenaran dan perubahan.
\end{abstract}

Kata kunci: Kontekstual, Eksistensi Yesus, Gereja Banua Niha Keriso

\section{PENDAHULUAN}

Kehadiran Yesus dalam dunia merupakan wujud kasih Allah bagi umat manusia untuk membebaskan dan menebus dari hukuman dosa melalui kematian Yesus di atas kayu salib. Setelah tuntas dan sempurna Ia menyelesaikan-Nya di atas kayu salib maka Ia dikuburkan dan pada hari yang ketiga Ia bangkit dari antara orang mati sesudah itu Ia naik ke sorga. Namun, sebelum Ia naik ke sorga Ia mengutus para murid-murid-Nya untuk pergi membaptis dan menjadikan bangsa menjadi murid-Nya dengan diperlengkapi dengan kuasa Roh Kudus. (Kis. 1:8). Dalam panggilan dan pengutusan para 
murid tersebut banyak orang yang percaya kepada-Nya sehingga terbentuk jemaat Tuhan di tengah-tengah dunia, itu sebabnya dapat dikatakan bahwa gereja merupakan persekutuan orang-orang yang telah beriman kepada Yesus Kristus. Itu artinya bahwa gereja bukanlah dari dunia karena eklesia sebagai sesuatu yang vertikal yang konstitusikan Allah; Allah sendirilah yang menghimpun jemaat-Nya. ${ }^{1}$ Dieter mengatakan bahwa, dalam Perjanjian Baru tampak suatu perkembangan gereja yang bergerak mulai dari gereja yang dibangun oleh Roh Kudus pada hari Pentakosta dan seterusnya ke arah pelembagaan gereja. ${ }^{2}$ Dalam perjalanannya maka gereja mulai berkembang saat itu hingga pada saat ini termasuk di pulau Nias. Di pulau Nias gereja yang paling besar adalah Banua Niha Keriso Protestan dan sudah ada dibeberapa kota di Indonesia. Cikal bakal berdiri Gereja Banua Niha Keriso Protestan merupakan inisiatif dari Tuhan untuk mengirim para misionaris dalam mengabarkan Injil pada tanggal 27 September 1865 yaitu Ludwig Ernst

1 Ana Telaumbanua, Skisma Gereja di Nias (Jawa Tengah, 2020), 1-2; Bobby Kurnia Putrawan. "Pengantar Latar Belakang Kitab Kisah Para Rasul (Introduction To Acts Background)." QUAERENS: Journal of Theology and Christianity Studies 1, no.2 (2019): 176-183.

https://doi.org/10.46362/quaerens.v1i2.8.

2 Dieter Becker, Pedoman Dogmatika (Jakarta: BPK Gunung Mulia, 2001), 170.

Denninger $^{3}$ sebagai utusan RMG (Rheinische Missions Gesselschaft). ${ }^{4}$ Dalam perkembangannya Gereja Banua Niha Keriso Protestan memiliki programprogram pelayanan dalam peningkatan pertumbuhan iman jemaat terkait dengan koinonia, didaskalia, oikonomia, marturia. Untuk mewujudkan program pelayanan ini semua warga jemaat dilibatkan bersama dengan para pelayan dalam setiap jemaat. Dalam mewujudkan misi dan visi agung Yesus Kristus di tengah-tengah dunia maka Gereja Banua Niha Keriso terpanggil untuk menjadi agent dalam transformasi kehidupan umat manusia secara utuh. Kendati Gereja Banua Niha Keriso Protestan mengalami perkembangan namun masih terdapat keraguan tentang keberadaan Yesus untuk berada ditengahtengah umat-Nya. Keraguan tersebut tampak dengan adanya umat Tuhan yang percaya kepada allah lain. Terjadi keraguan semacam itu disebabkan karena masih ada sisa-sisa kepercayaan suku Nias yang masih menguasai hidup warga jemaat dan para pelayan, seperti: kepercayaan kepada arwah nenek moyang, takyul dan ikatan-ikatan primodial serta pengaruh

\footnotetext{
${ }^{3}$ Ludwig Ernst Denninger lahir pada tanggal 4 Desember 1815 di kampung halamannya di Berlin-Jerman. Sebelum ia diutus menjadi misionaris, ia mengikuti pendidikan misionaris di Seminari Barmen di Wuppertal, Jerman.

${ }^{4}$ Ana Telaumbanua, Skisma Gereja di Nias, 9.
} 
kuasa kegelapan (Okultisme) dan adat istiadat yang cenderung mengutamakan kehormatan kepada manusia daripada Allah. ${ }^{5}$ Sesungguhnya bahwa orang yang sudah beriman kepada Tuhan maka memaknai keberadaan Yesus tersebut dengan bersifat teosentris bukan dengan menduakan Tuhan dalam aspek kehidupannya. Berdasarkan hal itu maka tulisan ini tentang teologi kontekstual ${ }^{6}$ tentang eksistensi Yesus pasca kenaikanNya di Gereja Banua Niha Keriso Protestan guna meletakkan dasar pemahaman bahwa Yesus maha hadir dalam setiap aspek kehidupan umat-Nya.

\section{METODE}

Tulisan ini menggunakan metodologi kualitatif yang merupakan pendekatan analisa mendalam dengan penalaran induktif menggunakan teknik analisa untuk memahami suatu masalah secara subyektif. Namun, sasaran metodologi kualitatif ini ialah untuk mendapatkan untuk mendapatkan teori-teori yang berhubungan dengan topik pembahasan. Dari teori-teori yang dibahas, kemudian

\footnotetext{
${ }^{5}$ Fotarisman Zaluchu (Editor), Tunaikan Tugas Pelayananmu (Medan: Citapustaka Media Perintis, 2010), 23-24.

6 Untuk memahami lebih lanjut tentang model-model teologi kontekstual silahkan mebaca buku Stephen Bevans. "Models of Contextual Theology." Missiology 13, no. 2 (April 1985): 185-202. https://doi.org/10.1177/00918296850130020 5.
}

dikembangkan untuk mendapatkan sintesa dari teori-teori yang sudah dibahas dan direfleksikan untuk menjawab persoalan yang ada di Gereja Banua Niha Keriso. ${ }^{7}$ Penelitian kualitatif ini dimulai dengan tahap refleksi, yaitu peneliti menentukan topik atau permasalahan, termasuk refleksi yang berhubungan dengan peneliti. ${ }^{8}$ Kemudian peneliti menggunakan metode pengumpulan data dengan wawancara, observasi, dan pemeriksaan dokumen, atau variasi dari metode-metode tersebut yang sesuai dengan penelitian kualitatif. ${ }^{9}$

\section{HASIL DAN PEMBAHASAN}

Dalam pembahasan ini akan diuraikan tentang gereja yang berteologi dalam konteks berdasarkan pendekatanpendekatan kontekstualisasinya dan aspek pemahaman tentang keberadaan pasca kenaikan-Nya di Gereja Banua Niha Keriso Protestan.

\section{Gereja yang Berteologi dalam Konteks}

Menurut Yakob Tomatala bahwa kontekstualisasi merupakan upaya bagaimana seharusnya setiap orang kristen berteologi dalam konteks/lingkungan

\footnotetext{
${ }^{7}$ Baca Yakob Tomatala dan Dr. Paskalinus Busthan, Penuntun Desain Riset bagi Program Tinggi Teologi (Jakarta: YT Leadership Foundation, 2010), 3.

8 Yakob Tomatala dan Dr. Paskalinus Busthan, 69.

${ }_{9}^{9}$ Andreas B. Subagyo, Pengantar Riset Kuantitatif dan Kualitatif (Bandung: Yayasan Kalam Hidup, 2014), hal 228.
} 
hidupnya secara utuh. ${ }^{10}$ Selain itu, teologi kontekstual merupakan ilmu teologi kristen yang menelaah bagaimana ajaran kristen dapat menjadi relevan di kontekskonteks yang berbeda. ${ }^{11}$ Dalam hal ini dapat dikatakan bahwa ajaran tentang Alkitab dapat memasuki setiap aspek kehidupan manusia tanpa mendapatkan tantangan dan hambatan sehingga Injil dapat diwartakan. Berteologi dalam konteks ini terkait dengan pelayanan Gereja Banua Niha Keriso yang harus dapat berteologi dalam konteksnya sendiri. Berikut diagram berteologi dalam konteks yang diadopsi dari buku Teologi Kontekstual yang ditulis oleh Yakob Tomatala (Gambar 1):

Gereja BNKP

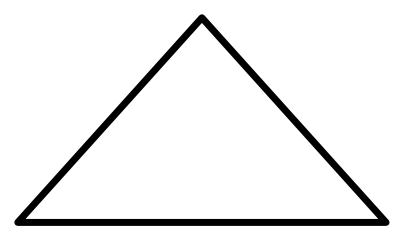

Konteks 1
Konteks Injil

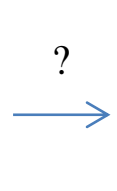

Berdasarkan diagram di atas maka dapat dikatakan bahwa sebagai gereja harus memaknai jati dirinya sebagai gereja yang merupakan panggilan yang Ilahi sebagai terang bagi dunia. Dalam tata

${ }^{10}$ Yakob Tomatala, Teologi Kontekstual (Malang: Gandum Mas, 2007), 2.

11 "Teologi kontekstual," dalam Wikipedia bahasa Indonesia, ensiklopedia bebas, 20 Oktober 2020, https://id.wikipedia.org/w/index.php?title=Teo logi_kontekstual\&oldid=17526554. gereja Banua Niha Keriso Protestan dan peraturan pelaksanaanya diungkapkan bahwa ada tiga tugas pokok panggilan gereja yaitu, Marturia yang mengacu tentang pemberitaan Injil Kristus, yaitu berita tentang pertobatan, pengampunan dosa dan keselamatan (Mark. 1:15; Luk. 24:47) serta kebebasan, keadilan, kebenaran, damai sejahtera kepada segala bangsa dan semua makluk (Mark. 16:15), sampai ke ujung bumi (Kis. 1:8) di seluruh alam dibawah kolong langit (Kol. 1:23) dan sampai pada akhir zaman (Mat. 28:20).

Koinonia yang merupakan tugas penampakkan keesaan gereja yang berdiri teguh dalam satu Roh, sebagai satu tubuh

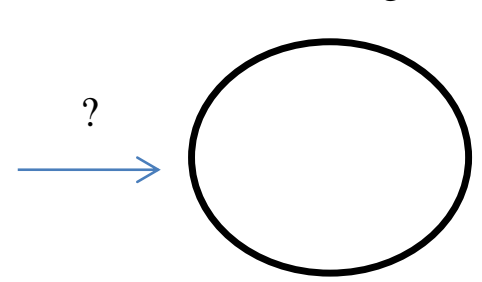

Konteks 3

yang sehati sepikir dan satu iman yang mengharuskan untuk saling memahami, memperhatikan dan melayani serta bertolong-tolongan dangan demi kepentingan bersama (Ef. 4:3-6; Fil. 2:4; 1 Kor. 12: 27). Keesaan dalam hal ini menurut pengertian rohani, yaitu keesaan seperti kesatuan Allah Bapa, Anak-Nya Yesus Kristus dan Roh Kudus (Yoh. 17:21-22). Diakonia mengacu tentang 
pelayanan untuk membebaskan manusia dari segala kemiskinan, kebodohan, kemeralatan, segala penyakit, ketidakadilan dan segala bentuk keterbelakangan dalam masyarakat, sebagaimana dilakukan oleh Yesus Kristus (Mat. 4: 24; Luk 4:18-19). ${ }^{12}$

Dalam tugas panggilan gereja ini memahami konteks penerima Injil itu sendiri sehingga dapat menerima dan memahami sehingga pada giliran terjadi transformasi pemahaman iman yang sesungguhnya. Memahami konteks penerima dari Injil secara utuh terkait dengan budayanya, tradisi yang berlaku dalam konteks tersebut. Yakob Tomatala menambahkan bahwa teologi kontekstualisasi refleksi ideal dari setiap orang kristen dalam konteks hidupnya atas Injil Yesus Kristus. Artinya bahwa bagaimana seharusnya Injil (yang utuh itu) ditaburkan sehingga membawa keseimbangan yang tampak dari refleksi teologi si penerima Injil (dari hakikat dirinya yang utuh secara pribadi atau kelompok, budaya, sosial, politik, ekonomi lokal dsb, dan keseluruhan perspektif orang-orang tersebut dalam konteksnya). ${ }^{13}$

12 Tata Gereja BNKP dan Peraturannya (Gunungsitoli, t.t.), 14.

13 Yakob Tomatala, Teologi Kontekstual, 2; Ebenhaezer I. Nuban Timo, Edim Bahabol, dan Bobby Kurnia Putrawa. "REVIVAL OF LOCAL RELIGION: A Challange for Church and National Life in Indonesia." MAHABBAH: Journal of Religion and Education 1, no.1 (2020): 71-86. https://doi.org/10.47135/mahabbah.v1i1.9.
Oleh karena itu, ia menambahkan bahwa, gereja memiliki gambaran diri sebagai "tubuh Kristus" yang memahami dan melihat dirinya sebagai tubuh Kristus yang dinyatakan dalam konteks, pola, bentuk, kerangka, dan sistem sosio-budaya lokal seutuhnya. ${ }^{14}$ Dengan demikian bahwa sebagai gereja sesungguhnya berteologi dalam menyatakan kebenarannya sebagai wakil Allah dalam bidang kehidupan manusia tanpa terkecuali untuk menjadi berkat dan teladan yang sesungguhnya.

\section{Pendekatan Teologi Kontekstual}

\section{tentang Eksistensi Yesus}

Eksistensi Yesus pasca kenaikan-Nya merupakan kenyataan yang ada, sebab Ia telah telah menyatakan bahwa Ia menyertai umat-Nya. (Band Mat. 28:20). Penyertaan umat-Nya sangat sempurna dengan memberikan kuasa Roh Kudus yang ditandai bahwa Ia memberikan keteguhan iman kepada umat-Nya. Itu umat-Nya sebagai gereja Tuhan tidak perlu meragukan kehadiran Yesus dalam dunia. Namun, demikian Gereja Banua Niha Keriso perlu memahami keberadaan Yesus dalam lingkungan konteks pelayanan. Untuk memahaminya maka beberapa

\footnotetext{
${ }^{14}$ Yakob Tomatala. Teologi Kontekstual, 88; Ebenhaezer I. Nuban Timo, Edim Bahabol, dan Bobby Kurnia Putrawa. "REVIVAL OF LOCAL RELIGION: A Challange for Church and National Life in Indonesia": 71-86.
} 
pendekatan yang perlu diperhatikan adalah pendekatan akomodasi yang ditandai dengan keterbukaan dalam menerima budaya asli dalam sikap dan perbuatan dalam mengemban tugas pelayanan penginjilan. Pendekatan adaptasi yang mengacu kepada upaya dalam mengasilimasikan unsur budaya untuk mengekspresikan Injil. Tentu pendekatan ini bertujuan untuk mewartakan tentang Injil dalam istilah setempat sehingga menjadi relevan dalam kondisi budaya setempat. Selain itu, pendekatan prossesio yang ditandai dengan upaya menanggapi kebudayaan secara negatif. Hal ini melalui seleksi, penolakan, dan reinterpretasi. Kemudian model transformasi mengacu kepada pemahaman bahwa Allah itu di atas budaya, dan melalui budaya itu Allah menggunakan elemen-elemen kebudayaan untuk bisa berkomunikasi dengan manusia.. Selanjutnya terkait dengan pendekatan diaklektik yang mengacu kepada upaya interaksi yang dinamis antara teks dengan konteks. ${ }^{15}$ Dengan demikian maka model pendekatan ini merupakan acuan dalam teologi kontekstual untuk memudahkan dalam mewartakan keberadaan Yesus di tengahtengah pelayanan berdasarkan dengan

15 Gillian M. Bediako. "Understanding Issues of Gospel and Culture." Presentation, Encountering African Christianity Seminar for Ghana Mission Network, 19-21 Juni 2011; Yakob Tomatala. Teologi Kontekstual, 77-79. konteks sehingga memahami dan menyadari bahwa Yesus tetap eksis dalam kehidupan umat-Nya.

\section{Memahami Yesus yang Bernatur Manusia dan Allah}

Yesus Kristus merupakan manusia yang sempurna dengan ditandai melalui proses kelahiran-Nya lewat perawan Maria tunangan Yusuf, akan tetapi Maria mengandung yang diperanakkan oleh Roh Kudus. Yesus bertumbuh besar sampai dewasa bahkan sampai pada titik penyaliban-Nya di atas kayu salib Ia terus memperlihatkan bahwa Ia adalah manusia yang sempurna antara lain: Ia memiliki tubuh manusia. (Luk. 2:40, 52) dan nyawa (Luk. 23: 46). Ia juga memiliki sifat-sifat manusia: Ia merasa lapar (Mat. 4:2), memiliki perasaan kekaguman (Mat. 8:10; Mark. 6:6), tidur (Mat. 8:24), tergerak oleh belas kasihan (Mat. 9:36), berdoa (Mat. 14:23), merasa haus (Yoh. 19:28), merasa letih (Yoh. 4:6), merasa sedih (Yoh. 11: 35), dan mengalami kematian (Yoh. 19:30). Dalam natur kemanusiaan-Nya ini Ia bukan seperti manusia biasa yang hidup dalam kedagingan dan keberdosaan tetapi Ia adalah manusia dengan tidak cacat cela dan tercemar bahkan tidak sama dengan dunia. $^{16}$

${ }^{16}$ Arif Yupiter Gulo, Tujuh Perkataan Yesus di Kayu Salib (Jawa Tengah: Penerbit Lakesiha, 2020), 19. 
Selain itu, dalam kemanusiaan-Nya ini dalam formulasi gereja purba menjelaskan bahwa pribadi Kristus selalu mengandung juga penjelasan tentang fungsi soteriologi-Nya. Sebaliknya, tidak mungkin kita menggambarkan karya Kristus tanpa mengenal pribadi-Nya. ${ }^{17}$ Itu sebabnya ketika Ia sudah menyelesaikan pekerjaan-Nya, Ia naik ke sorga. Kenaikan-Nya menunjukkan secara badani bahwa Ia naik ke surga, yang menandai bahwa Dialah orang Nazaret pertama yang masuk surga dan sebagai mata rantai yang menghubungkan pekerjaan di bumi dan di surga. Dialah perintis yang mendahului masuk dan mengambil sepenuhnya di dalam kemuliaan Tuhan Allah Bapa di surga, dalam kekuasaan dan pemerintahanNya. ${ }^{18}$ Kendati Ia menunjukkan kemanusiaan-Nya maka Ia juga Allah. Berbicara tentang Ke-Allahan-Nya ditandai bahwa Ia memiliki sifat-sifat Allah, yaitu kekekalan (Yoh. 1:1-3; 8:58; 13:1; 17:5), maha hadir (Mat. 28: 20), maha tahu (Mat. 16:21, Luk. 6:8, 11:7, Yoh. 2:24-25, 4:29, 16:30, 21:17), dan maha kuasa (Mat. 28: 20, Mark. 1:29-34,

\footnotetext{
17 Dieter Becker, Pedoman Dogmatika, 117118.

18 Santosa' Irfaan, “Kebangkitan - Kenaikan Yesus dan Israj' - Mi'raj Muhammad: Kajian Perbandingan" Al-Qalam Jurnal Penelitian Agama dan Sosial Budaya, 19, no. 94 (JuliSeptember 2002) (2002): 98. https://media.neliti.com/media/publications/2 82887-kebangkitan-kenaikan-yesus-dan-isramira-b16a2aaf.pdf.
}

5: 11-15, Luk. 8:25, Yoh. 11: 38-44), Ia melakukan hal-hal yang dilakukan Allah, seperti memberi pengampunan kepada orang berdosa (Mat. 9:6, Mrk. 2:1-2), memberikan kehidupan rohani (Yoh. 5:21), membangkitkan orang mati (Yoh. 11:43), menghakimi semua orang (Yoh. 5:22, 27), Ia memiliki nama Allah (Yoh 1: 3), dan Ia adalah anak Allah (Luk. 1:32, Yoh. 10:36), Ia mengaku bahwa Ia dan Bapa adalah satu (Yoh. 10:30) dan Ia disembah sebagaimana Allah disembah (Mat. 28:9, Yoh 9:38). Dalam hal ini John Stott mengatakan bahwa, Yesus bukanlah sosok yang historis (memang Dia adalah sosok yang ada dalam sejarah) melainkan juga kekal (bahkan "sama kemarin, hari ini dan selamanya). ${ }^{19}$ Berdasarkan pernyataan ini menekankan bahwa Yesus tetap eksis sampai saat ini kendati dunia roboh dan runtuh tetapi Ia tetap ada sebagai Allah yang hidup sampai selama-lamanya. Dalam Kisah Para Rasul dinyatakan bahwa, jadi seluruh kuam Israel harus tahu dengan pasti, bahwa Allah telah membuat Yesus, yang kamu salibkan itu, menjadi Tuhan dan Kristus. (Kis. 2:36). Kesaksian yang menarik ketika kedua orang buta yang berteriak memohon pertolongan dengan mengenal dan memahami keberadaan Yesus yang sesungguhnya dengan mengatakan bahwa, Ya, Tuhan

${ }^{19}$ John Stott, Kristus yang Tiada Tara (Surabaya: Momentum, 2013), 4. 
kasihanilah kami. Kedua orang buta ini dengan iman mengatakan bahwa Yesus bukan hanya manusia akan tetapi sebagai Tuhan yang memiliki kuasa. (Mat. 20:31). Demikian juga Maria Magdalena setelah peristiwa kebangkitan Yesus dengan bukan hanya mengaku Yesus sebagai Rabi akan tetapi juga mengakui Yesus adalah Tuhan. (Yoh. 20:18). Dalam hal ini maka Maria Magdalena menyaksikan bahwa Yesus adalah Tuhan sebagai pencipta langit dan bumi beserta segala isinya.

\section{Eksistensi Allah: Ia adalah Allah dalam}

\section{Konteks}

Yesus Kristus bukan berasal dunia ini. Itu sebabnya tatkala Ia sudah menyelesaikan tugas-Nya, Ia kembali sorga untuk menyediakan tempat bagi umat yang percaya kepada-Nya. Kendati Ia sudah naik ke sorga dengan menerima kemuliaan yang sempurna akan tetapi Ia adalah Allah yang kekal yang menunjukkan keberadaan-Nya yang tidak dapat dibatasi oleh ruang dan waktu. Oliver mengatakan bahwa, dalam gereja mula-mula mengungkapkan bahwa Yesus Kristus telah ada di sorga untuk menyatakan keuniversalan ke-Allahan-Nya dan dikatakan bahwa ia juga ada dalam dunia. $^{20}$ Oliver menambahkan bahwa, Dia

${ }^{20}$ Oliver Davies, Theology of Transformation. (Oxford: University Press, 2013), 5. nyata dalam arti bahwa dia melampaui pengalaman yang kita miliki tentang dia, dan memang semua kemungkinan pengalaman yang mungkin kita miliki tentang dia. Mengatakan bahwa Dia universal sama saja dengan mengatakan bahwa Kristus hidup dengan cara yang berarti dia tidak terbatas oleh ruang dan waktu. $^{21}$ Selanjutnya Oliver menegaskan bahwa, Dia hadir tentu saja dalam kekhususannya, atau dalam apa yang kita sebut identifikasi dirinya, tetapi tidak dibatasi oleh ruang dan waktu. Sebagai Penguasa ruang dan waktu, Kristus ada dalam ruang dan waktu, tetapi dirinya sendiri tidak tunduk padanya. ${ }^{22}$ Berdasarkan pemahaman tersebut maka eksistensi Allah dalam konteks tidak dapat dibatasi yang ditandai bahwa Ia ada dalam konteks budaya dan politik dan dalam aspek-aspek kehidupan manusia lainnya. Itu sebabnya Yakob Tomatala mengatakan bahwa, gereja yang berteolog dalam konteks tentu memahami dimensi teologi yang absah yang menekankan bahwa,

Alkitab adalah firmah Allah sebagai norma iman dan perbuatan bagi dan dalam budaya, dan menekankan keagungan Allah sang pencipta, tidak bercampur dengan ciptaan, Ia tetap menguasai jagat raya serta memelihara. Kemudian, Yesus Kristus Allah yang mulia yang

\footnotetext{
21 Oliver Davies. Theology of Transformation, 5.

22 Oliver Davies. Theology of Transformation , 5.
} 
sesungguhnya manusia dan Allah. Selanjutnya, menekankan tentang Roh Kudus yang Allah yang sejati dan berperan memberi kuasa, menolong dan membimbing orang kepada Kristus serta memenuhinya untuk hidup suci, dan menjadi saksi Kristus. $^{23}$

Dengan demikian dapat dikatakan bahwa sebagai gereja memahami keberadaan Yesus dengan mutlak dengan tidak dapat dibatasi dalam konteks kehidupan manusia. Dalam Ibrani 13: 8 dinyatakan bahwa, Yesus Kristus tetap sama, baik kemarin maupun hari ini dan sampai selama-lamanya. Hal ini disebut dengan alfa dan omega yang artinya yang awal dan yang akhir (Wahyu 21:6).

\section{Eksistensi-Nya Mutlak tanpa Diinter- vensi Konteks}

Konteks pelayanan gereja berbeda dalam beberapa aspek. Pelayanan gereja memproklamirkan Injil tentang Yesus Kristus. Namun, tatkala memproklamirkan Injil khususnya dalam pelayanan gereja Banua Niha Keriso Protestan tentu memiliki budaya dan tradisinya sendiri. Namun, eksistensinya tidak dapat diubahkan dan dikurangi justru eksistensi untuk menerangi setiap budaya dan tradisi tersebut. Jika kita memperhatikan kehadiran Yesus datang ke tengah-tengah dunia bukan karena inisiatif umat manusia,

\footnotetext{
23 Yakob Tomatala, Teologi Kontekstual, 75.
}

namun kehadiran dan kedatangan-Nya ke dalam dunia merupakan inisitif dari Tuhan untuk untuk berada di tengah-tengah umat manusia. Tatkala Ia berada di tengahtengah umat manusia dengan berbagai aspek yang dihadapi baik budaya dan tradisi yang ada Ia tidak terikat dengan budaya dan tradisi tersebut. Hal tersebut terbukti terkait dengan percakapan-Nya dengan perempuan Samaria. Dalam artikel Berilah Aku Minum mengungkapkan bahwa,

Yesus telah memberikan
keteladanan dimana Ia melayani
bukan hanya kepada orang Yahudi
saja tetapi kepada orang-orang yang
bukan orang Yahudi dan juga kepada
orang-orang Samaria. Pelayanan
Yesus kepada orang Samaria terbukti
tatkala Ia melintasi daerah samaria
dengan melakukan percakapan kepada
perempuan Samaria (Yoh. 4:1-42).
Perjumpaan dan percakapan ini tidak
lazim bagi orang Yahudi disebabkan
karena orang Yahudi tidak bergaul
dengan orang Samaria daerah
Samaria ini merupakan wilayah
perkawinan campur antara orang
Yahudi dan bangsa lain, itulah
sebabnya wilayah ini dikatakan
kafir. ${ }^{24}$

Namun, Yesus mengubah budaya dan tradisi tersebut dengan menjalin hubungan dengan siapapun tanpa terkecuali. Hal ini menunjukkan bahwa Ia tidak dapat diintervensi dengan budaya dan tradisi. Itu

\footnotetext{
${ }^{24}$ Arif Yupiter Gulo, "Berilah Aku Minum: Mengungkap Makna Dialogis Yesus dengan Perempuan Samaria Berdasarkan Yohanes 4:7b," Integritas: Jurnal Teologi Volume 2, Nomor 2, Desember 2020 (2020): 178.
} 
sebabnya gereja harus tegak lurus dalam memaknai tentang eksistensi Yesus tersebut bahwa sebagai gereja tidak dapat diikat dan kuasai dengan budaya dan tradisi konteks yang telah ada dalam lingkungan pelayanan gereja sehingga eksistensi Yesus dapat diberitakan dan proklamirkan dengan efektif sehingga setiap orang mendengarkan yang pada gilirannya mendapatkan keselamatan dan kehidupan yang kekal.

\section{Gereja sebagai Wakil Allah dalam Menyatakan Kebenaran}

Sebelum Ia naik ke sorga, Ia mengutus murid-murid-Nya untuk menyatakan kebenaran melalui pemberitaan Injil (Band. Mat.28:19-20). Hal ini menunjukkan bahwa Yesus memerintahkan umat-Nya menjadi saksi kebenaran. (Band. Luk. 24:48). Oleh karena itu, Ia menekankan tentang peranan umat-Nya dalam mewujudkan rencanaNya dalam dunia ini supaya setiap orang yang percaya kepada-Nya mendapatkan kehidupan yang kekal. Kebenaran Allah merupakan pusat sentral dalam kehidupan manusia tanpa kebenaran maka semuanya akan sia-sia dan hampa. Sesungguhnya kebenaran adalah Yesus Kristus sebab Ia pernah berkata bahwa Akulah jalan dan kebenaran dan hidup. Tidak ada seorang pun yang datang kepada Bapa, kalau tidak melalui Aku. (Yoh. 14:6).
Oleh karena itu, berbicara tentang sebagai wakil Allah ini dapat dikatakan bahwa Gereja mengemban tugas Allah yang disebut sebagai Missio Dei. Allah menghendaki bahwa kerajaan Allah harus dinyatakan di bumi ini. ${ }^{25}$ Dalam pemahaman di atas menekankan bahwa gereja sebagai wakil Allah untuk menyatakan kebenaran-Nya yang telah diproklamirkan dengan nyaring bahwa bertobatlah kerajaan Allah sudah dekat. Kerajaan Allah mengacu kepada pemerintahan Allah yang kekal yang tidak dapat runtuh dan roboh bahkan tetap berdiri dalam dunia ini. Hery berpendapat bahwa Gereja sebagai kumpulan orangorang percaya harus tetap mengarahkan setiap program dan pemikirannya sesuai dengan apa yang Kristus kehendaki.

Konsekuensi logisnya adalah gereja harus mengarahkan hati dan pikiran sesuai apa yang Kristus kehendaki yaitu menjadi saksi kebenaran dan mengajak orang lain untuk dapat meneladani apa yang Yesus ajarkan. ${ }^{26}$ Itu artinya bahwa gereja bukan hanya simbol yang tampak indah dari luar melainkan gereja dengan fungsi dan tugasnya untuk menyatakan kerajaan Allah di dunia sebab Ia berkata bukan kamu yang memanggil Aku, tetapi Akulah yang memilih kamu. Dan Aku telah menetapkan

${ }^{25}$ Hery Susanto, "Gereja Yang Berfokus Pada Gerakan Misioner," Jurnal Fidei, 2, no.1 (June 2019): 65.

26 Hery Susanto, 66. 
kamu, supaya kamu pergi dan menghasilkan buah dan buahmu itu tetap, supaya apa yang kamu minta kepada Bapa dalam nama-Ku diberikan-Nya kepadamu. (Yoh. 15-16). Dengan demikian gereja berbuah bukan hanya dalam aspek kuantitas tetapi dalam segi aspek kualitas, iman yang berkualitas yang mengacu kepada pemahaman dan pengenalan akan Yesus Kristus. Paulus menegaskan bahwa, Hendaklah kamu berakar di dalam Dia dan dibangun di atas Dia, hendaklah kamu bertambah teguh dalam iman yang telah diajarkan kepadamu, dan hendaklah hatimu melimpah dengan syukur. (Kol. 2:7).

\section{Gereja sebagai Wujud Tuhan Allah dalam Perubahan}

Gereja sebagai wujud kehadiran Allah bukan gedung gerejanya yang megah dengan berbagai macam asesorisnya yang menarik dan menawan serta memikat hati akan tetapi gereja sebagai wujud Allah adalah umat-Nya yang terpanggil untuk melakukan perubahan secara utuh. Dikatakan bahwa jemaat adalah gereja sebagai wujud Allah yang kelihatan sebab Paulus mengatakan bahwa tubuh kita itu adalah bait Allah. Itu sebabnya harus di bangun iman yang tampak untuk dilihat orang. Paulus menekankan bahwa, janganlah serupa dengan dunia ini berubahlah dengan akal budimu. (Roma 12:2). Berbicara tentang perubahan ini maka dalam buku Tunaikan Tugas Pelayananmu mengungkapkan bahwa perubahan artinya lahirnya sesuatu yang baru dan benar-benar baru. Melalui keberadaan kita dikomunitas, kita dituntut membawa dan melahirkan perubahan. Bukan justru menunda terjadi perubahan dengan alasan tradisi. Perubahan adalah proses untuk maju. ${ }^{27}$ Artinya gereja sebagai wujud Allah dalam kehidupan manusia semakin memancarkan terang yang sudah meninggalkan kehidupan lama melainkan sudah memiliki kuasa Roh. Kuasa Roh dimaksud dalam hal ini seperti ungkapan Paulus di jemaat Galatia 5:22-24 dinyatakan bahwa, kasih, sukacita, damai sejahtera, kesabaran, kemurahan, kebaikan, kesetiaan, kelemahlembutan, penguasaan diri, tidak ada hukum yang menentang hal-hal itu. ${ }^{28}$ Selain itu, terkait dengan perubahan maka ditegaskan bahwa ada beberapa tipe orang dalam menyikapi perubahan yakni,

\footnotetext{
27 Fotarisman Zaluchu (Editor), Tunaikan Tugas Pelayananmu, 49.

${ }^{28}$ Abraham Waigi Ng'ang'a. "Why Contextual Theology Matters for the Church." InSights Journal for Global Theological Education 3, no.1 (November 2017): 25-32; Band. Kuasa Allah dalam Elia, Hadi Widoyo, Christian Ade Maranatha, dan Yohanes Ndapamuri. "Kuasa Allah Dalam Elia Dam Implikasinya Bagi Umat Tuhan Pada Masa Kini (God's Power In Elia And The Implications For The People Of The Lord Now)." QUAERENS: Journal of Theology and Christianity Studies, 2, no.1 (2020): 19-29. https://doi.org/10.46362/quaerens.v2i1.20.
} 
Tipe orang yang anti perubahan. Tipe ini orang yang mempertahankan 'status quo'. Tipe ini dalam pelayanan Yesus yang mengacu kepada kaum farisi. Kelompok ini takut dengan dinamika perubahan yang terjadi saat Yesus mulai terlihat mengajar di mana-mana. Mereka takut akan perubahan karena merugikan kepentingan mereka sendiri. Tipe kedua adalah orang yang mengikuti perubahan. Kelompok ini ketika perubahan terjadi justru menerjunkan diri didalamnya dan mengikuti arus perubahan tersebut. Tentu perubahan dalam hal ini ke hal-hal yang positif. ${ }^{29}$

Berdasarkan hal itu Gereja Banua Niha Keriso hadir sebagai wujud Allah sebagai agent pembaharuan dalam menerangi dan memurnikan budaya, politik dan ekonomi dan aspek kehidupan lainnya. Terkait dengan perubahan ini maka dalam buku Tunaikan Tugas Pelayanan mengungkapkan peranan Gereja dalam merubah kehidupan bergereja yang telah memaknai keberadaan Allah dalam kehidupannya yang ditandai dengan yakni:

Sosial change yang mengacu pada perubahan sosial dari pola tradisional kepada pola modernisasi. Oleh karena itu Gereja sebagai wujud Allah berusaha untuk meningkatkan cara hidup masyarakat dengan bersedia meninggalkan kehidupan lama yang dapat menghambat kemajuan masyarakat. Attitude change yang ditandai dengan manusia secara individu atau kelompok selalu memiliki sikap tertentu terhadap orang lain atau kelompok di luar dirinya dan juga terhadap hal-hal baru yang dijumpainya. Opinion change setiap

${ }^{29}$ Fotarisman Zaluchu (Editor), 50. orang atau kelompok bahkan setiap budaya memiliki pandangannya sendiri tentang dunia dan manusia serta tentang budaya lain. Behaviour change yang mengacu tentang perubahan kelakuan manusia yang kental dengan tradisional, akan tetapi hal ini harus diubah menjadi perilaku positif. Spiritual change yang ditandai dengan kehidupan rohani dan semangat beragama yang terus dipertahankan dan jika belum mengalami perubahan terkait dengan spiritual ini maka harus diupayakan untuk lebih meningkat dan berkembang. ${ }^{30}$

Dengan demikian dapat dikatakan bahwa gereja sebagai wujud Allah memiliki peran dalam mengubah dirinya dan juga dalam aspek kehidupan lainnya. Melalui transformasi yang utuh tersebut menunjukkan tentang eksistensi Yesus yang tetap ada di tengah-tengah dunia ini sehingga gereja bersifat dinamis dan menjadi berkat.

\section{KESIMPULAN}

Keberadaan Yesus pasca kenaikan-Nya di Gereja Banua Niha Kerios Protestan tidak menjadi perdebatan yang merugikan iman kekristenan. Bahkan dalam persepktif pengakuan iman gereja Iman Banua Niha Keriso Protestan menempatkan Yesus sebagai pusat pemberitaan yang tidak bisa ditawar-tawar. Dalam perpektif teologi kontekstual tentang eksistensi Yesus pasca kenaikanNya menunjakkan bahwa Ia adalah Alllah

\footnotetext{
30 Fotarisman Zaluchu (Editor), 60-61.
} 
yang dalam setiap aspek kehidupan manusia yang di tandai bahwa Gereja merupakan wakil untuk menyatakan kebenaran sekaligus gereja-Nya juga merupakan wujud kehadiran-Nya dalam transformasi kehidupan bergereja.

\section{KEPUSTAKAAN}

Bediako, Gillian M. "Understanding Issues of Gospel and Culture." Presentation, Encountering African Christianity Seminar for Ghana Mission Network, 19-21 Juni 2011.

Bevans, Stephen. "Models of Contextual Theology." Missiology 13, no. 2 (April 1985): 185-202.

https://doi.org/10.1177/009182968501 300205.

Davies, Oliver. Theology of Transformation. Oxford: University Press, 2013.

Dieter Becker. Pedoman Dogmatika. Jakarta: BPK Gunung Mulia, 2001.

Gulo, Arif Yupiter. "Berilah Aku Minum: Mengungkap Makna Dialogis Yesus dengan Perempuan Samaria Berdasarkan Yohanes 4:7b." Integritas: Jurnal Teologi 2, Nomor 2, Desember 2020 (2020).

Irfaan, Santosa'. 'Kebangkitan - Kenaikan Yesus dan Israj' - Mi'raj Muhammad: Kajian Perbandingan" Al-Qalam Jurnal Penelitian Agama dan Sosial Budaya, 19, no. 94 (2002): 93-116. https://media.neliti.com/media/publicat ions/282887-kebangkitan-kenaikanyesus-dan-isra-mira-b16a2aaf.pdf.

Ng'ang'a, Abraham Waigi. "Why Contextual Theology Matters for the Church." InSights Journal for Global Theological Education 3, no.1 (November 2017): 25-32.

Putrawan, Bobby Kurnia. "Pengantar Latar Belakang Kitab Kisah Para Rasul (Introduction To Acts Background)." QUAERENS: Journal of Theology and Christianity Studies 1, no.2 (2019): 176-183.

https://doi.org/10.46362/quaerens.v1i2. 8.

Stott, John. Kristus yang Tiada Tara.

Surabaya: Momentum, 2013.

Subagyo, Andreas B. Pengantar Riset

Kuantitatif dan Kualitatif. Bandung:

Yayasan Kalam Hidup, 2014.

Susanto, Hery. "Gereja Yang Berfokus

Pada Gerakan Misioner." Jurnal Fidei

2, no.1 (June 2019): 62-80.

—. Tujuh Perkataan Yesus di Kayu

Salib. Jawa Tengah: Penerbit Lakesiha, 2020.

Tata Gereja BNKP dan Peraturannya. Gunungsitoli, t.t.

"Teologi kontekstual." Dalam Wikipedia bahasa Indonesia, ensiklopedia bebas, 20 Oktober 2020.

https://id.wikipedia.org/w/index.php?ti tle=Teologi_kontekstual \&oldid=17526554.

Telaumbanua, Ana. Skisma Gereja di Nias. Jawa Tengah, 2020.

Timo, Ebenhaezer I. Nuban, Edim Bahabol, dan Bobby Kurnia Putrawa. "REVIVAL OF LOCAL RELIGION: A Challange for Church and National Life in Indonesia." MAHABBAH: Journal of Religion and Education 1, no.1 (2020): 71-86. https://doi.org/10.47135/mahabbah.v1i 1.9.

Tomatala, Yakob. Teologi Kontekstual. Malang: Gandum Mas, 2007.

Tomatala, Yakob \& Busthan, Paskalinus. Penuntun Desain Riset bagi Program Tinggi Teologi. Jakarta: YT Leadership Foundation, 2010.

Widoyo, H., Christian Ade Maranatha, dan Yohanes Ndapamuri. "Kuasa Allah Dalam Elia Dam Implikasinya Bagi Umat Tuhan Pada Masa Kini (God's Power In Elia And The Implications For The People Of The Lord Now)." QUAERENS: Journal of Theology and Christianity Studies, 2, no.1 (2020): 19-29. 
https://doi.org/10.46362/quaerens.v2i1. 20.
Zaluchu, Fotarisman (Ed.). Tunaikan Tugas Pelayananmu. Medan:

Citapustaka Media Perintis, 2010. 